\title{
ПРИКОСНОВЕНИЕ К ДРЕВНОСТИ: СТРАНИЦЫ БИОГРАФИИ УЧЕНОГО (к юбилею К.М. Карабаспаковой)
}

\author{
(C) 2018 г. М.В. Бедельбаева
}

В статье очерчены основные вехи жизненного пути Культай Мухамедьевны Карабаспаковой - археолога, музейного работника, преподавателя. Ее имя хорошо знакомо профессионалам - исследователям проблем эпохи бронзы Евразии. В юности, познав романтику поиска в геологических экспедициях, Культай Мухамедьевна мечтала стать историком, археологом. Своими учителями она считает К.А. Акишева и Г.Б. Здановича. Основные научные интересы К.М. Карабаспаковой связаны с изучением эпохи бронзы Жетысу и Южного Казахстана.

Ключевые слова: археология, К.М. Карабаспакова, Жетысу, эпоха бронзы, археологическая культура, научные исследования, университет, музей

Культай Мухамедьевна Карабаспакова родилась 14 сентября 1948 г. в городе Целиноград (Астана) в семье служащего. Отец - Карабаспаков Мухамедья Карабаспакович, 1910 года рождения, начинал железнодорожным рабочим, впоследствии был направлен для обучения в г. Москву, после чего успешно начал карьеру руководящего работника, завершив ее в должности первого секретаря горкома партии г. Акмолинска. Мать - Исмагулова Гульсум Исмагуловна, 1920 года рождения, была домохозяйкой и воспитывала пятерых детей.

В 1955 г. К.М. Карабаспакова пошла в первый класс СШ № 1 в Акмолинске, а после окончания восьмого класса в Гурьеве (Атырау) поступила в медицинское училище, где обучалась с 1963 по 1966 годы и закончила его с отличием. Далее с
1966 по 1970 годы в ее жизни была работа медицинской сестрой сначала в Гурьеве, а после в Целинограде. За это время начинающий медик попробовала себя во всех направлениях: снимала электрокардиограммы, ассистировала стоматологу, познавала терапию, но постепенно теряла интерес к профессии, осознав неизменный алгоритм оказания медсестринской помощи, без творчества и новизны. «Не мое», - решила она и последующие два года успешно отработала техником-геологом во всесоюзной комплексной изыскательной экспедиции № 31 института «Гидропроект». Запись в трудовой книжке в эти годы: «За достигнутые высокие производственные показатели в соревновании в честь 50-летия Ленинского плана ГОЭЛРО объявить К.М. Карабаспаковой благодарность». И поощрение 
Бедельбаева М.В. Прикосновение к древности: страницы биографии ученого...

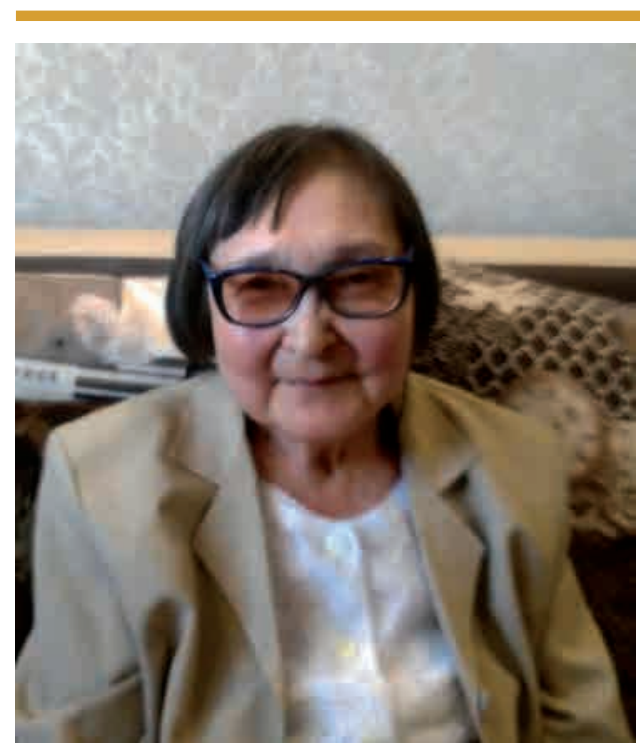

Рис. 1. Культай Мухамедьевна Карабаспакова. Фото В.Г. Ломана, 2018 г.

Fig. 1. Kultay M. Karabaspakova. Photo by V.G. Loman, 2018

это не единственное - помимо благодарностей фото передовика было занесено на доску почета, что свидетельствовало не только о том, что ее ценило начальство, но уважал и коллектив. Возможно и продолжился бы ее жизненный путь в геологии, но, случайно, будучи проездом в Караганде в череде будней полевых экспедиций, прочла сообщение в газете об открытии исторического факультета в новом университете и решила воплотить свою мечту стать археологом. На вступительных экзаменах в КарГУ сдавала только один предмет «История СССР» и, получив «отлично», сразу была зачислена в вуз, где обучалась с 1972 по 1977 годы.

Из воспоминаний юбиляра: «Сидя на лекциях вместе с Виктором Варфоломеевым [ныне к.и.н., доцент кафедры археологии, этнологии и Отечественной истории КарГУ им. академика Е.А. Букетова - прим. авт.] и обсуждая с ним полученную информацию, я очень любила задавать лекторам уточняющие вопросы, которые зачастую воспринимались ими как отвлекающие и провокационные, за что не раз была изгнана из аудиторий» [из личной беседы с К.М. Карабаспаковой - прим. авт.]. Во время обучения специализировалась по археологии. Уже на первом курсе ей довелось слушать лекции именитых ученых, мэтров археологии - Лии Яковлевны Крижевской [специалист по археологии эпохи камня из Ленинградского отделения Института археологии - прим. авт.]; Геннадия Борисовича Здановича [специалист по эпохе бронзы - прим. авт.]; Мира Касымовича Кадырбаева [исследователь археологии раннего железного века - прим. авт.]. Удивительно, что отличница по жизни (и в приложении к «красному» университетскому диплому подавляющее большинство «пятерок») два основных курса по археологии, читаемых Г.Б. Здановичем - «История первобытного общества» и «Основы археологии» - К.М. Карабаспакова сдала на «хорошо». Видимо, это было связано с требовательностью преподавателя, почувствовавшего особый интерес студентки к данным дисциплинам, и желающим показать безграничность процесса познания.

Со студенческих лет она выезжала в археологические экспедиции в Северный и Центральный Казахстан, участвовала в раскопках поселений Саргары, Петровка II, Усть-Кенетай, могильников Алыпкаш, Сатан, Карагаш и др. Именно с этим периодом и связано начало ее активной исследовательской деятельности, а также участие в студенческих научных конференциях.

Дипломную работу «Металлические изделия эпохи бронзы Ка- 
захстана» студентка К. Карабаспакова писала под руководством к.и.н. В.В. Евдокимова. Она вспоминает, что была полностью погружена в новизну проблематики, поскольку материала было мало и даже основополагающая работа Н.А. Аванесовой по аналогичной теме к тому времени еще не была издана. Заинтересованность и компетентность в данном вопросе позволили ей даже поспорить с научным руководителем на процедуре защиты, который в своем отзыве оценил работу на «хорошо». Удачей было присутствие М.К. Кадырбаева, который был проездом в Караганде, посетил исторический факультет, поучаствовал в процессе защиты и высоко оценил проделанную работу, сравнив материалы диплома с готовой кандидатской диссертацией. Такая поддержка вдохновила и аттестационную комиссию, и саму дипломницу.

В 1977 г. сразу после получения диплома с отличием К.М. Карабаспакова осталась работать на одной из кафедр исторического факультета в должности старшего инженера, что по тем временам было большой редкостью и свидетельствовало о перспективности выпускницы и признании ее научного потенциала. С января 1980 г. она работала директором открывшегося при университете музея археологии и этнографии. При ее непосредственном участии в марте 1981 г. была смонтирована первая «пилотная» экспозиция, демонстрирующая не столько подлинные артефакты, сколько историю изучения

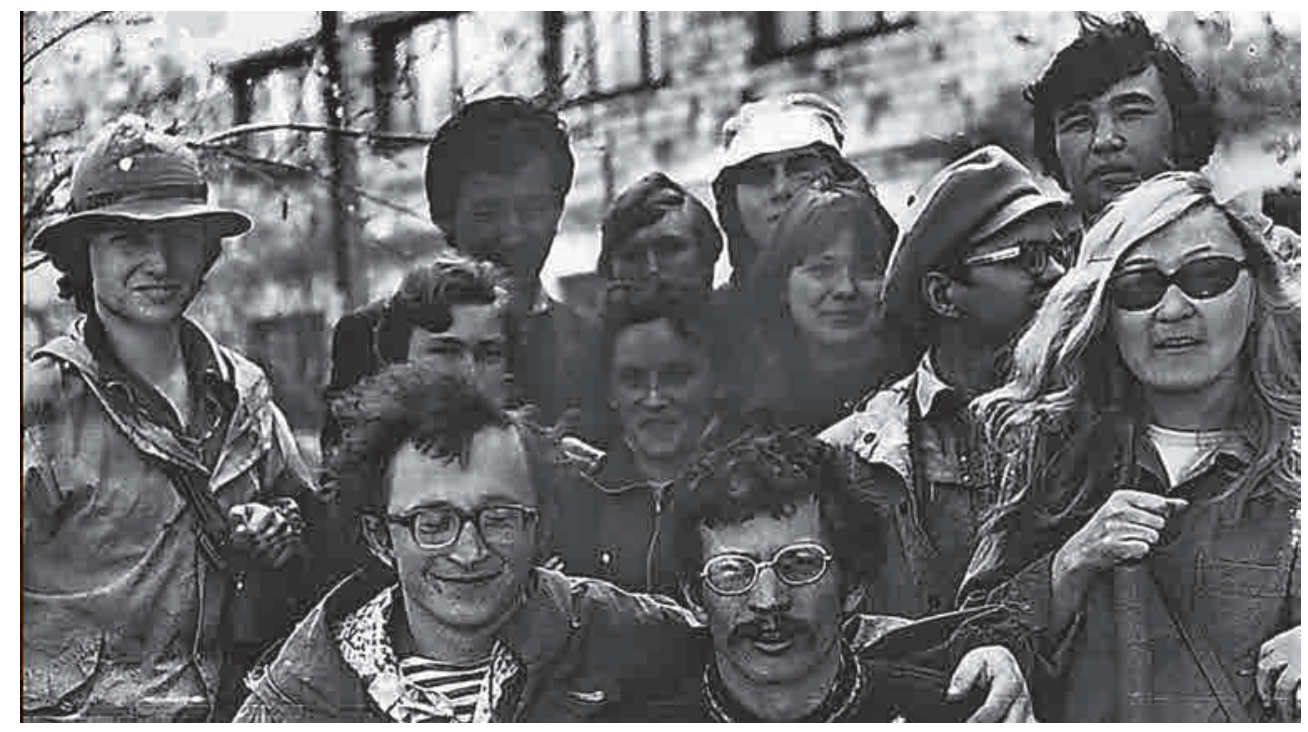

Рис. 2. Перед экспедиичей. Конеи 1970-х гг. Первый ряд (слева-направо)

А.П. Мазниченко, А.А.Ткачев, А.Д. Таиров, К.М. Карабаспакова, второй ряднеизвестный, Л. Тетерина, О. Гуменчук, В.В. Евдокимов, третий ряд-неизвестный, С. Мельник, А.Ю. Чиндин, Б. Токпанов.

Фото из архива музея археологии и этнографии САИ

Fig. 2. Before the expedition. The end of the 1970s. First row (from left to right) Maznichenko, A. P., Tkachev, A. A., Tairov, A. D., Karabaspakova, K. M.; second rowunknown, Teterina, L., Gumenchuk, O., Evdokimov, V. V.; third row-unknown, Melnik, S., Chindin, A. Yu., Tokpanov, B.

Photo from the archives of the Museum of Archaeology and Ethnography SAI 
Бедельбаева М.В. Прикосновение к древности: страницы биографии ученого...

археологических памятников Центрального Казахстана со стендовой подачей фотоматериала и прорисовками. В 1985 г. состоялась официальная церемония открытия новой экспозиции музея, включающей 20 витрин с экспонатами археологии и раздел этнографии. С музеем, прошедшим целый ряд реорганизаций [отдел археологии, лаборатория-музей, музей при исследовательском институте прим. авт.], деятельность К.М. Карабаспаковой была тесно связана в течение многих лет, вплоть до ухода на пенсию в 2005 г.

Уже в 1981 г. она поступила в целевую аспирантуру по специальности «Археология» при Институте истории, археологии и этнографии им. Ч.Ч. Валиханова АН КазССР, где обучалась до марта 1986 года. К.М. Карабаспакова вспоминает об этом в своей статье: «В те годы поступить в аспирантуру было большой удачей, поскольку целевые места выделяли крайне редко и мне пришлось несколько лет ждать этой возможности. По завершении сдачи вступительных экзаменов я была приглашена в кабинет К.А. Акишева и он сам предложил мне научное руководство» [Карабаспакова, 2014, с. 56]. С этого момента ее судьба была связана с К.А. Акишевым, которого она считает своим учителем в науке, и с неисследованной ранее темой «Жетысу и Южный Казахстан в эпоху бронзы», призванной заполнить лакуну в археологии. Благодаря «благословению» К.А. Акишева, Культай Мухамедьевна стояла у истоков бронзоведения Жетысу. Известных к тому времени памятников было мало, большую часть их еще предстояло найти. Так произошло ее дальнейшее становление как самостоятельного исследователя-археолога.
В середине 1980-х гг. она была начальником отряда по исследованию памятников эпохи бронзы Жетысу в составе Семиреченской археологической экспедиции. Это звучит весомо, но на самом деле Культай Мухамедьевне приходилось выполнять функции землекопа, чертежника, экспедитора, повара и она спокойно делала всю эту работу. Результатом этой самоотверженной и плодотворной деятельности стали десятки раскопанных памятников, нередко расположенных в труднодоступной местности. Ею исследованы многие яркие памятники Жетысу - могильники Айдархан, Арасан, Буйен, Талапты 1, 2, Мыншункыр, поселения Буйен, Ащибулак, Теренкара и др. Это недели и месяцы напряженного труда при любых погодных условиях и обстоятельствах. Специфика научного исследования и повседневной работы была абсолютно другая, чем в музее и университете. Необходимо было проявлять больше самостоятельности, принимать порой рискованные решения, брать ответственность на себя и со всем этим достойно справлялась хрупкая женщина.

И вновь цитата из статьи юбиляра: «Сейчас я осознаю, что была нестандартна: отчиталась на Ученом Совете о проделанной работе рукописью диссертации, прошла предзащиту, скинула груз с плеч и... пропала. Выпала на последующие годы, занимаясь детьми, семьей, преподаванием. Для меня факт признания моих достижений в науке не был столь важен. Официальный статус значил для меня меньше, чем одобрение К.А. Акишева. Именно по его настойчивой просьбе, высказанной в конце 1990-х гг., я защитила свою диссертацию и искренне благодарна всем коллегам, которые помогли мне в этом» 
[Карабаспакова, 2014, с. 58]. Культай Мухамедьевна всегда трепетно и с особой теплотой вспоминает своего учителя, благодаря которому стала настоящим профессионалом в археологии.

В 1998 году К.М. Карабаспакова защитила диссертацию на соискание ученой степени кандидата исторических наук по специальности «Археология» (07.00.06.) по теме «Племена Семиречья и Южного Казахстана в эпоху бронзы». Работа была выполнена в Институте археологии им. А.Х. Маргулана Академии наук Республики Казахстан. В диссертационном исследовании, используя свои полевые материалы, архивные отчеты и публикации коллег, она тщательно проанализировала и обобщила имеющийся к тому времени комплекс источников. Коллеги-археологи, высоко оценивая рукопись диссертации, отмечали основательность теоретической базы и доскональный разбор накопленных материалов. Это была успешная попытка создания цельной картины бронзового века южного региона - древние культуры рассматривались в контексте их происхождения, развития и характера хозяйственной деятельности населения. К.М. Карабаспакова выделила новую буйенскую (биенскую) культуру эпохи поздней бронзы Жетысу, образовавшуюся в результате миграций и взаимовлияния нескольких культур. Глубина проблематики сочеталась со скрупулезным анализом материала и всесторонней аргументацией. Ее выводы и заключения, подтвержденные временем и новыми исследованиями, органично вписываются в общую канву современного бронзоведения. Благодаря личной инициативе А.3. Бейсенова этот материал был издан через 13 лет после защиты без дополнений в виде монографии, продолжая оставаться актуальным и интересным, поскольку некоторые проблемы, обозначенные К.М. Карабаспаковой, ждут подобного пытливого исследователя, ведь процесс научного познания бесконечен.

После окончания аспирантуры К.М. Карабаспакова работала старшим преподавателем на кафедре исторического факультета, которая в разные годы называлась по разному истории Казахстана; древнего мира; археологии и этнологии; археологии, этнологии и Отечественной истории. Это был большой и важный период в жизни, когда она, обучая студентов, читала курсы по «Основам археологии», археологии Казахстана, средневековой истории Казахстана и спецкурсы по древней истории и археологии. С апреля 2000 г. по декабрь 2003 г. работала доцентом на кафедре археологии, этнологии и Отечественной истории.

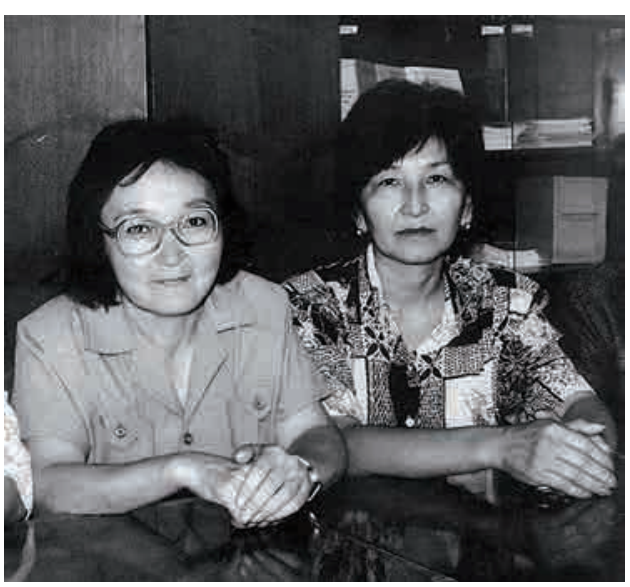

Рис. 3. К.М. Карабаспакова и

Б.М. Абдрахманова на кафедре истории Казахстана. Начало 1990-х. г2.

Фото из архива музея археологии и этнографии САИ

Fig. 3. Karabaspakova, K. M. and Abdrakhmanova, B. M. at the Department of History of Kazakhstan. The early 1990s. Photo from the archives of the Museum of Archaeology and Ethnography SAI 
Бедельбаева М.В. Прикосновение к древности: страницы биографии ученого...

Преподавательская деятельность К.М. Карабаспаковой - отдельная тема. Студенты всегда с благодарностью отзывались о ее занятиях, запоминающихся массой информации, аналитикой, эрудицией лектора. Всех удивляло ее уважительное отношение к молодежи; отсутствие назидательности; ее своеобразная манера говорить - медленно, вдумчиво, слегка картавя, как бы предлагая размышлять вместе; лаконичные, но вместе с тем убедительные формулировки и выводы; неординарное видение проблем археологии и древней истории. При всем при этом «дипломники» К.М. Карабаспаковой сталкивались с небывалой требовательностью и даже жесткостью своего научного руководителя. По словам выпускника исторического факультета О. Шариязданова [в настоящее время к.и.н., руководитель археологических фондов и музея Международной тюркской академии, г. Астана - прим. авт.], его дипломная работа «Археологическая карта Шетского района Карагандинской области» далась ему, что называ- ется, «потом и кровью» - множество консультаций, провокационных вопросов, ценных советов и постоянное совершенствование готового текста. Зато на защите научный руководитель с «открытым забралом» отстаивал отличную оценку для своего питомца, видимо, вспоминая подобный случай из своей биографии.

Вот какими воспоминаниями поделился Н. Смагулов - бывший студент, впоследствии коллега по кафедре, а в настоящее время кандидат исторических наук, руководитель управления анализа Департамента внешнеполитического анализа и прогнозирования МИД РК: «Образ Культай Мухамедьевны в воспоминаниях студенческих лет запечатлелся в самых красочных тонах. Каждый студент в группе, выступая на семинарах или сдавая рефераты, стремился не оплошать, чтобы не подпасть под град ироничных замечаний этого мастера утонченной словесности. Для нее всегда был характерен изящный юмор, от которого частенько становилось дискомфортно ее безответ-

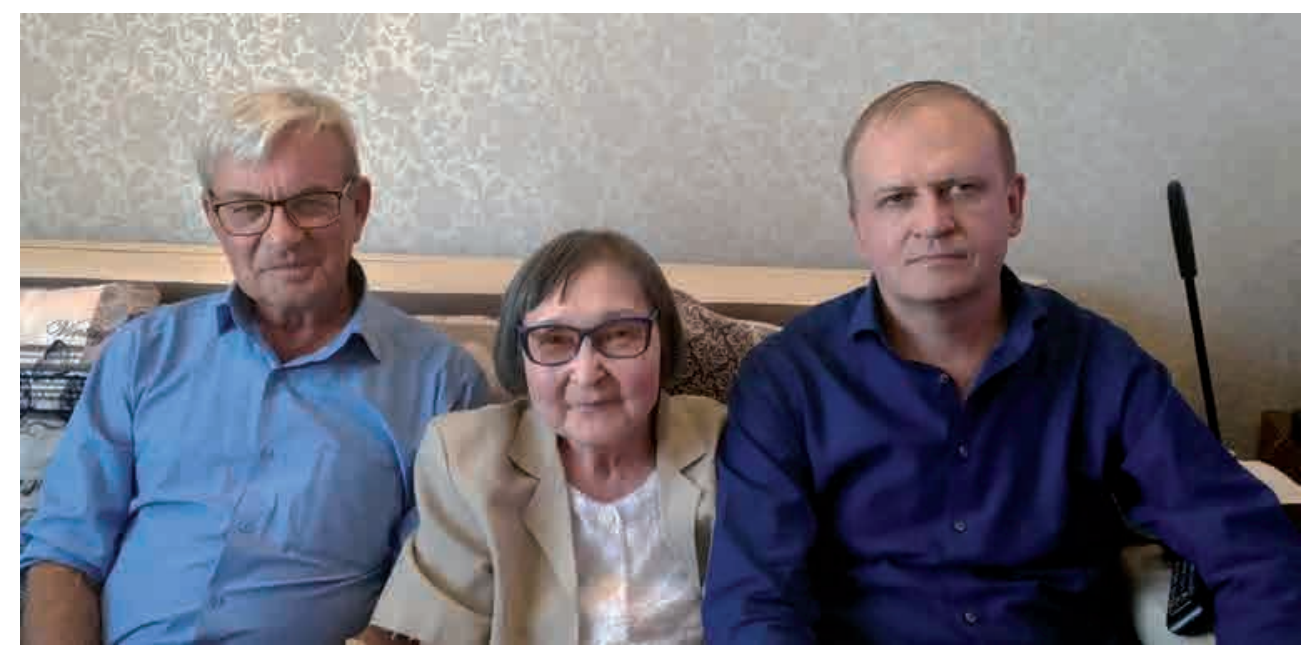

Рис. 4. К.М. Карабаспакова и карагандинские археологи В.В. Варфоломеев и В.Г. Ломан. 2018 г. Фото из архива музея археологии и этнографии САИ

Fig. 4. Karabaspakova, K. M. and archaeologists Varfolomeev, V. V. and Loman, V. G. 2018. Photo from the archives of the Museum of Archaeology and Ethnography SAI 
ственным ученикам. Она заставляла человека задумываться над процессом собственного самосовершенствования, при этом не заостряя внимания на недостатках. Наоборот, после общения с ней недостатки волшебно превращались в достоинства. Впоследствии, став коллегами, я раскрыл для себя множество удивительных сторон её замечательного характера и, прежде всего, безграничную самоотдачу в работе. Терпеливый и внимательный собеседник, остроумный полемист, всесторонне эрудированный преподаватель, позитивный человек, талантливый педагог - это лишь маленькая толика тех качеств, которые я так хотел бы иметь в своем жизненном багаже, видя положительный для себя пример в лице Культай Мухамедьевны Карабаспаковой» [из личной беседы с Н.К. Смагуловым - прим. авт.].

Доброжелательным и опытным наставником помнят Культай Мухамедьевну и те студенты, кому посчастливилось поработать с ней на археологической практике в ходе исследований поселения финальной бронзы Бугулы I. Это была середина-конец 1990-х гг. - последние годы, когда К.М. Карабаспакова могла выехать в полевые условия. Позднее это стало невозможным из-за тяжелой болезни, с которой она стойко борется по сей день, не теряя веры в будущее. Стаж ее работы в археологических экспедициях более 30 лет и этот бесценный опыт объясняет филигранную методику раскопок профессионального полевика, высокий профессионализм и неугасимое любопытство к непознанному.

Еще в студенческие годы среди друзей, а позднее и коллег, ее стали называть «Кыпчачкой» - первоначально за этим стояла принадлежность к родовому подразделению. С годами стало ясно, что подоплека второго имени гораздо глубже и свидетельствует о житейской мудрости и спокойствии Культай Мухамедьевны, умноженных достойным воспитанием и образованием, национальными традициями и уверенностью в себе. К.М. Карабаспакова состоялась и в личной жизни, воспитав двух дочерей.

Цитируя А.З. Бейсенова, следует признать, что: «Эта хрупкая, маленькая женщина сказала свое слово в археологии Казахстана...» [Бейсенов, 2011, с. 6]. Выражая свою признательность и уважение, хочется пожелать Культай Мухамедьевне долгих лет жизни, много света, добра, высокого полёта её утонченного юмора и счастья общения с внуками!

\section{ЛИТЕРАТУРА}

1. Карабаспакова К.М. Пример служения науке... // Восхождение к вершинам археологии: сб. матер. междунар. научн. конф. «Древние и средневековые государства на территории Казахстана», посвящ. 90-летию со дня рождения К.А. Акишева. Алматы: Институт археологии им. А.Х. Маргулана, 2014. С. 56-58.

2. Бейсенов А.З. От редактора // Карабаспакова К.М. Жетысу и Южный Казахстан в эпоху бронзы. Алматы: НИЦИА «Бегазы-Тасмола», Институт археологии им. А.Х. Маргулана, 2011. С. 5-6. 
Бедельбаева М.В. Прикосновение к древности: страницы биографии ученого...

\section{Список публикаций К.М. Карабаспаковой}

Автореферат:

Племена Семиречья и Южного Казахстана в эпоху бронзы: автореф. дис. ... канд. ист. наук. Алматы: Институт археологии им. А.Х. Маргулана, 1998. 26 с.

\section{Монография:}

Жетысу и Южный Казахстан в эпоху бронзы. Алматы: НИЦИА «Бегазы-Тасмола», Институт археологии им. А.Х. Маргулана, 2011. Отв. ред. А.З. Бейсенов. 220 с., илл.

Статьи:

Статистическая обработка керамического поселения Саргары // VI Уральская научная студенческая археологическая конференция: тез. докл. Ижевск: Удмурт. гос. ун-т им. 50-летия СССР, 1974. С. 34-35.

Могильник Бийликуль - памятник ранней бронзы Южного Казахстана // Бронзовый век степной полосы Урало-Иртышского междуречья. Челябинск-Уфа: изд-во Башкирского ун-та, 1983. С. 152-158 (в соавт. с Мотовым Ю.А.).

К вопросу о культурной принадлежности памятников эпохи поздней бронзы СевероВосточного Семиречья и их связями с памятниками Центрального Казахстана // Вопросы периодизации археологических памятников Центрального и Северного Казахстана. Караганда: изд-во КарГУ, 1987. С. 90-101.

Исследования памятников эпохи бронзы в долине р. Биен (северо-восточное Семиречье) // АО-1985. М.: «Наука», 1987. С. 570-571.

Роль инновации в сложении биенской культуры поздней бронзы Семиречья // Проблемы археологии Степной Евразии: тез. докл. - Кемерово: изд-во КемГУ, 1987. Ч. 1. С. $97-101$.

Новые памятники эпохи бронзы Восточного Семиречья // Древние памятники Северной Азии и их охранные раскопки. Новосибирск: б.и., 1988. С. 24-39 (с соавт. с Марьямевым А.Н.).

Жертвенный баран в системе погребального обряда эпохи бронзы // Актуальные проблемы методики западносибирской археологии. Новосибирск: б.и., 1989. C. $159-160$.

Этнокультурные связи населения эпохи поздней бронзы Семиречья (по материалам могильника Арасан) // Первые Маргулановские чтения. Алма-Ата: ИИиЭ им. Ч. Валиханова, 1989. С. 95-97.

Погребальный обряд как палеосоциологический источник (по материалам могильника Кумган II) // Проблемы исторической интерпретации археологических и этнологических источников Западной Сибири. Томск: Том. гос. ун-т им. В.В. Куйбышева, 1990. С. 63-65.

Историко-культурные процессы в Семиречье в эпоху бронзы // Тез. докл. XVI научн.практ. конф. профессорско-преподавательского состава, научных работников, аспирантов и студентов. Караганда: изд-во КарГУ, 1991. С. 18-19.

Этнокультурная ситуация в Семиречье в эпоху поздней бронзы // Проблемы культур начального этапа эпохи поздней бронзы Волго-Уралья. Саратов: изд-во Сарат. унта, 1991. С. 12-14.

К вопросу о становлении Семиреченского очага металлообработки в эпоху бронзы // Маргулановские чтения. Петропавловск: Институт археологии им. А.Х. Маргулана, 1992. С. 49-51.

К вопросу об изучении древностей эпохи бронзы на территории Семиречья и Южного Казахстана // Букетовские чтения: тез. докл. межвуз. конф. Караганда: изд-во КарГУ им. академика Е.А. Букетова, 1992. С. 147-149.

К проблеме выделения основных центров и периферийных очагов внутри андроновской культурно-исторической общности // Казахстан между Западом и Востоком: 
проблемы национальной и всемирной истории. Караганда: изд-во КарГУ им. академика Е.А. Букетова, 2000. С. 52-60.

Пример служения науке... // Восхождение к вершинам археологии: сб. матер. междунар. научн. конф. «Древние и средневековые государства на территории Казахстана», посвящ. 90-летию со дня рождения К.А. Акишева. Алматы: Институт археологии им. А.Х. Маргулана, 2014. С. 56-58.

\section{Сведения об авторе:}

Бедельбаева Марина Васильевна - кандидат исторических наук, заведующая музеем археологии и этнографии, Сарыаркинский археологический институт, Карагандинский государственный университет им. академика Е.А. Букетова (г. Караганды, Казахстан); bmv_1967@mail.ru

\section{КӨНЕМЕН ЖАНАСУ: ҒАЛЫМНЫН ӨМІРБАЯН ЖОЛДАРЫ (К.М. ҚАРАБАСПАҚОВАНЫН МЕРЕЙТОЙЫНА)}

\section{М.В. Беделбаева}

Мақалада археолог, мұражай қызметкері, мұғалім Күлтай Мұхамедқызы Қарабаспақованың өмір жолының негізгі кезеңдері қарастырылған. Оның есімі Еуразияныңқоладәуірініңмәселелерінзерттеушілергежақсытанымал.Жастықшағында геологиялық экспедициялардың ізденістерді ертерек таныған Күлтай Мұхамедқызы тарихшы, археолог болуды армандады. К.А. Ақышев пен Г.Б. Здановичтерді өзінің ұстаздары санайды. К.М. Қарабаспақованың негізгі ғылыми қызығушылықтары Жетісу және Оңтүстік Қазақстан қола дәуірін зерттеумен байланысты.

Түйін сөздер: археология, К.М. Қарабаспақова, Жетісу, қола дәуірі, археологиялық мәдениет, ғылыми зерттеу, университет, мұражай

\section{TOUCHING TO ANCIENCY: SCIENTIST BIOGRAPHY PAGES (for the anniversary of K.M. Karabaspakova)}

\section{M.V. Bedelbayeva}

The article outlines the main landmarks of the life path of Kultai Mukhamedevna Karabasakova, an archaeologist, museum worker, teacher. Her name is well known to professional researchers of the Bronze Age of Eurasia. In her youth, having learned the romance of searching in geological expeditions, she dreamed of becoming a historian, an archeologist. She considers K.A. Akishev and G.B. Zdanovich as her teachers. The main scientific interests of K.M. Karabaspakova are associated with the study of the bronze epoch of Jetysu and South Kazakhstan.

Keywords: archaeology, K.M. Karabaspakova, Jetysu, Bronze age, archaeological culture, research scientific, University, museum

\section{REFERENCES}

1. Karabaspakova, K. M. 2014. In Baitanayev, B. A., Baipakov, K. M. (Ed.) Voskhozhdenie $k$ vershinam arheologii: sb. mater. mezhdunar. nauchn. konf. «Drevnie i srednevekovye gosudarstva na territorii Kazahstana», posvyashch. 90-letiyu so dnya rozhdeniya K.A. Akisheva (Climbing to the heights of archeology: mater. International scientific conf. "The ancient and medieval states in the territory of Kazakhstan, " dedicated the 90th anniversary of the birth of K.A. Akishev). Almaty: A. Kh. Margulan Institute of Archaeology Publ., 56-58. 
Бедельбаева М.В. Прикосновение к древности: страницы биографии ученого...

2. Beisenov, A. Z. 2011. In Beisenov, A. Z. (Ed.) Karabaspakova, K. M. Jetysu i Yuzhnui Kazakhstan v epohu bronzy (Jetysu and South Kazakhstan in the Bronze Age). Almaty: NICIA «Begazy-Tasmola», A.Kh. Margulan Archaeology Institute Publ., 5-6.

About the Author:

Bedelbayeva Marina V. Candidate of historical sciences, director archaeology and ethnography museum, Saryarka archaeological Institute, Karagandy state university after academician E.A. Buketov, Karagandy, Kazakhstan; bmv_1967@mail.ru

Мақала туралы ақпарат / Информация о статье / Information about the article.

Жариялауға қабылданды / Принята к публикации / Accepted for publication: 26.09.2018. 